\title{
Effect of ascorbic acid on seed germination of three halophytic grass species under saline conditions
}

\author{
A. Zehra, F. Shaikh, R. Ansari, B. Gul and M. A. Khan \\ Institute of Sustainable Halophyte Utilization (ISHU), University of Karachi, Karachi, Pakistan
}

\begin{abstract}
Grasses on the Pakistani coast are moderately to highly salt tolerant and have potential for utilization as a cash crop. This study was designed to determine whether seed germination of three halophytic grasses (Phragmites karka, Dichanthium annulatum and Eragrostis ciliaris) could be improved by exogenous application of ascorbic acid (AsA) under saline conditions. Seeds of P. karka were germinated in varying concentrations of $\mathrm{NaCl}$ and AsA under different temperature regimes, and seeds of Dichanthium annulatum and Eragrostis ciliaris were germinated at optimal temperatures only. In $P$. karka, concentrations of AsA (5 and $10 \mathrm{mM}$ ) alleviated the salinity effects better at cooler and moderate thermo-periods, whereas higher concentrations (20 $\mathrm{mM}$ of AsA) failed to improve germination under all temperature regimes. AsA was ineffective at a warmer thermo-period $\left(25 / 35^{\circ} \mathrm{C}\right)$. The rate of germination also increased at all thermo-periods with the application of AsA except at $25 / 35^{\circ} \mathrm{C}$ under saline conditions. Application of AsA improved the germination of E. ciliaris seeds under saline conditions but was inhibitory for D. annulatum in comparison with the untreated control. The rate of germination followed the similar pattern as that of seed germination. Results indicate that AsA has the ability to partially alleviate the effect of salinity on seed germination of some grass species under optimal temperature regime.
\end{abstract}

Keywords: grasses, salinity, semi-arid, Phragmites karka, Dichnathium annulatum, Eragrostis ciliaris, Pakistan

Correspondence to: Dr M. Ajmal Khan, Institute of Sustainable Halophyte Utilization, University of Karachi, Karachi75270, Pakistan

E-mail: majmalk@uok.edu.pk

Received 19 May 2011; Revised 14 June 2012

\section{Introduction}

Conventional domesticated crops face serious problems in completing their life cycle in regions characterized by severe drought, warm temperatures and high salinity. Inducing salt tolerance in these crops, either through conventional breeding or through modern molecular methods, is difficult to achieve because the trait is under multigenic control (Agarwal et al., 2012). Attention has consequently shifted to those plants that are already adapted to saline conditions and can be utilized as non-conventional cash crops (Koyro et al., 2011). The Institute of Sustainable Halophyte Utilization, the University of Karachi, Pakistan, is screening local halophytes for their fodder, forage, medicinal, oil seed and other economically useful characteristics (Khan et al., 2006b).

Initiation of seed germination is coupled with mitochondrial activity, which leads to the production of reactive oxygen species (ROS; Schopfer et al., 2001; Garnczarska and Wojtyla, 2008; Kranner et al., 2010). This ROS production may protect germinating seeds from pathogens (Schopfer et al., 2001), softening the cell wall (Müller et al., 2009) to promote radicle emergence and oxidize inhibitors (Ogawa and Iwabuchi, 2001).

Ascorbic acid (AsA) is widely distributed in plants and is a potent antioxidant that donates electrons in a wide range of enzymatic and non-enzymatic reactions (Arrigoni and De Tullio, 2000; Horemans et al., 2000; Smirnoff, 2000; Foyer and Noctor, 2011). It scavenges different ROS, such as superoxide, hydroxyl radicals and singlet oxygen, directly or indirectly, for regulating their cellular concentrations within narrow tolerable ranges (Kocsy et al., 2001; Shao et al., 2006, 2008). AsA is also required for the biosynthesis of different plant hormones, such as gibberellins, and ethylene, in addition to its role as an antioxidant, and therefore could be important for germination (De Tullio and Arrigoni, 2003). There is evidence of a correlation between seed germination capacity and the AsA system, because mature orthodox seeds lack AsA (De Tullio and Arrigoni, 2003). Increasing the AsA content 
by exogenous application may therefore be beneficial for seed germination of some species, particularly under salinity stress, which is known to accelerate the ROS production in plants (Noctor and Foyer, 1998; Hernández and Almansam, 2002). Khan et al. (2006a) reported such beneficial effects of exogenous AsA on seed germination of halophytes under salt stress; however, the responses were species specific.

Phragmites karka (Retz.) is a widely distributed grass in Pakistan found along streams and in wet grasslands and swamp. It is capable of withstanding heavy floods, which makes it an excellent stabilizer of erosion-prone river banks. It is also a source of lignocellulosic biomass for ethanol production (Abidin et al., 2011) and is grazed in some regions of New Guinea (Rosa-Innes, 1977). Dichanthium annulatum (Forssk.) Stapf is a perennial halophytic fodder grass eagerly sought by grazing livestock and is commonly found in the salt flats of the Karachi region. Eragrostis ciliaris (L.) R. Br. is an annual grass that is also distributed widely in salt flats and usually develops after monsoon rains; it is also readily grazed (Cope, 1982).

We report the role of AsA in alleviating the effect of salinity on seed germination of P. karka, D. annulatum and E. ciliaris. An initial study with P. karka helped us to select an optimal temperature regime for the study.

\section{Materials and methods}

Seeds of the three grass species were collected during September 2009 from the Karachi University campus, then separated from the inflorescence, cleaned and stored at room temperature. During October, seeds were surface-sterilized with $1 \%$ sodium hypochlorite before commencing the experiment. Twenty-five seeds in four replicates were germinated in $5 \mathrm{~mL}$ water or saline solution using air-tight plastic Petri dishes kept in growth cabinets. Germination (emergence of radicle) was recorded every alternate day for 20 days. The rate of germination was calculated with the help of a modified Timson's index of germination velocity $\left(=\sum G / t\right)$ where $G$ is the percentage of seed germinated after 20 days and $t$ is the total time of germination (Khan and Ungar, 1999).

Seeds of $P$. karka were germinated in six concentrations of $\mathrm{NaCl}$ (0, 100, 200, 300, 400 and $500 \mathrm{~mm}$ ) with or without AsA (5, 10, $20 \mathrm{~mm}$ ) in $12 \mathrm{~h}$ light/ $12 \mathrm{~h}$ dark photoperiod $\left(25 \mu \mathrm{mol} \mathrm{m}^{-2} \mathrm{~s}^{-1} ; 400\right.$ $700 \mathrm{~nm}$ cool white fluorescent Philips lamps, Karachi, Pakistan) at four temperature regimes (10/20, 15/25, $20 / 30$ and $25 / 35^{\circ} \mathrm{C}$ ) simulating night/day conditions. Seeds of $D$. annulatum and E. ciliaris were germinated similarly, in incubators as described above, but only at $20 / 30^{\circ} \mathrm{C}$ with different concentrations $(5,10,20$,
Table I Three-way ANOVA for percentage germination and rate of germination in seeds of Phragmites karka.

\begin{tabular}{|c|c|c|}
\hline \multirow[b]{2}{*}{$\begin{array}{c}\text { Independent } \\
\text { variables }\end{array}$} & \multicolumn{2}{|c|}{ Dependent variables } \\
\hline & $\begin{array}{c}\text { Germination } \\
(\%)\end{array}$ & $\begin{array}{l}\text { Germination } \\
\text { (Rate) }\end{array}$ \\
\hline Temperature $(\mathrm{T})$ & $566 \cdot 43$ & $962 \cdot 37$ \\
\hline $\mathrm{NaCl}(\mathrm{S})$ & $157 \cdot 76$ & $220 \cdot 97$ \\
\hline Ascorbic acid (AsA) & $214 \cdot 23$ & $287 \cdot 75$ \\
\hline $\mathrm{T} \times \mathrm{S}$ & $4 \cdot 65$ & $7 \cdot 96$ \\
\hline $\mathrm{T} \times$ AsA & 39.94 & $68 \cdot 23$ \\
\hline $\mathrm{S} \times \mathrm{AsA}$ & $24 \cdot 82$ & $34 \cdot 82$ \\
\hline $\mathrm{T} \times \mathrm{S} \times \mathrm{AsA}$ & $3 \cdot 67$ & $4 \cdot 32$ \\
\hline
\end{tabular}

Numbers represent $F$-values significant at $P<0.0001$.

$25 \mathrm{~mm}$ ) of AsA and salinity 0, 25, 75, 100, 125 and $150 \mathrm{~mm} \mathrm{NaCl}$ for E. ciliaris and 0, 100, 200, 300, 400 and $500 \mathrm{~mm} \mathrm{NaCl}$ for D. annulatum. Most previous studies had indicated that $20 / 30^{\circ} \mathrm{C}$ is an optimal temperature regime for the seed germination of

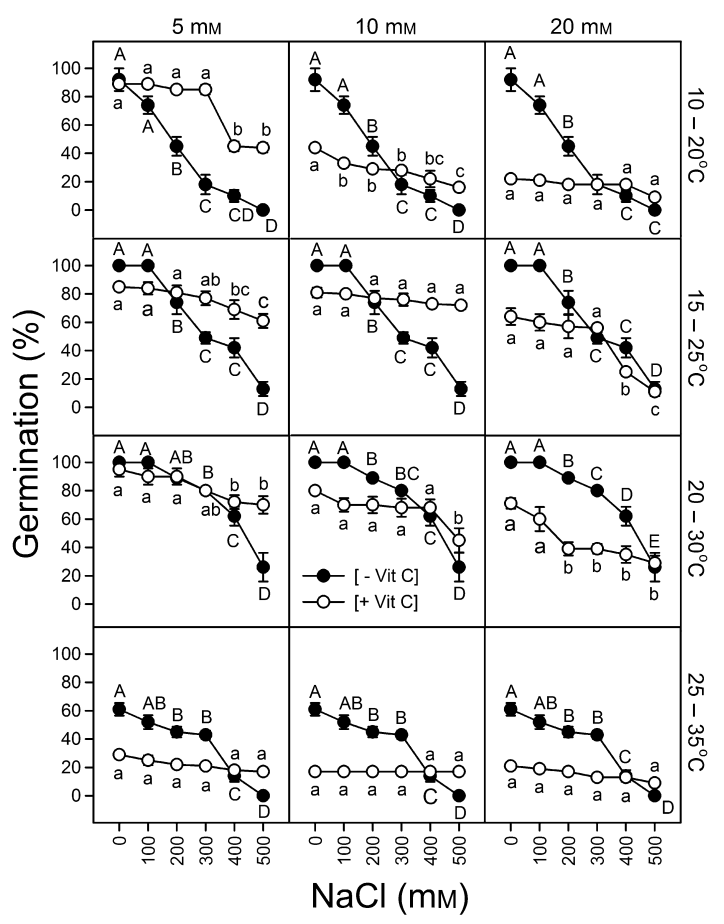

Figure I Effect of $\mathrm{NaCl}$ with and without various concentrations of ascorbic acid (AsA) on seed germination of Phragmites karka at various thermo-periods. The same letters within each AsA concentration indicate non-significant $(P>0.05)$ differences (Bonferroni test) at the end of the experiment. 


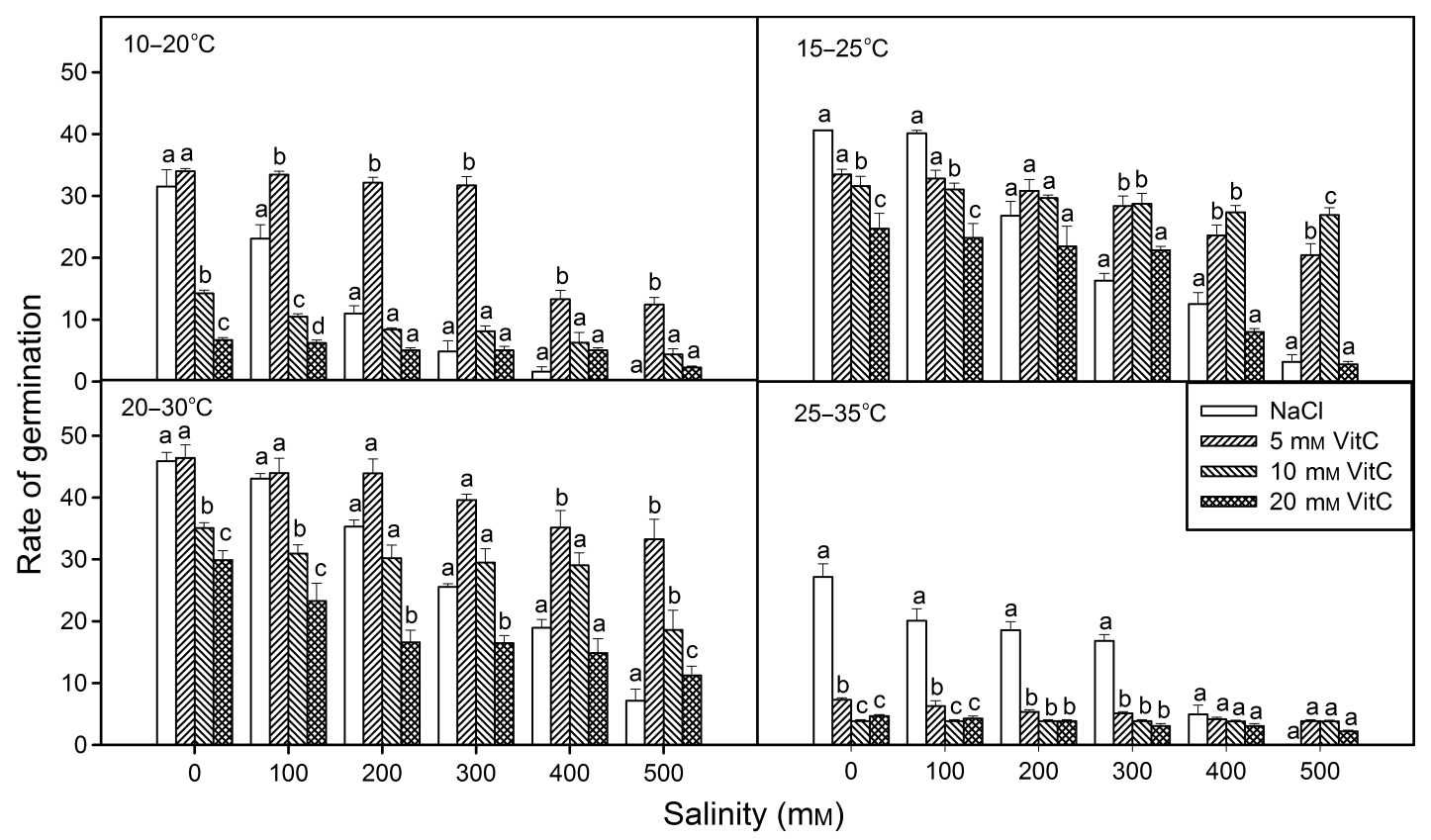

Figure 2 Effect of $\mathrm{NaCl}$ with and without various concentrations of ascorbic acid on germination rate of Phragmites karka at different temperature regimes. The same letters within each salinity concentration indicate non-significant $(P<0.05)$ differences (Bonferroni test) at the end of the experiment.

subtropical species. Analysis of variance (ANOva) was used to test for significance of differences between treatments (SPSS, 1999) and their interactions. The Bonferroni test (a multiple-range test) was carried out to determine significance $(P<0.05)$ between individual treatments.

\section{Results}

\section{Phragmites karka}

A three-way ANOva indicated significant $(P<0.0001)$ individual effects of salinity, temperature, AsA and their interactions on seed germination of P. karka (Table 1). Increase in both salinity and temperature decreased germination (Figure 1). Low levels of AsA (5 mм) significantly alleviated salinity effects, which were prominent especially at $10 / 20^{\circ} \mathrm{C}$. Here, even at the high salinity of $500 \mathrm{~mm} \mathrm{NaCl}$, about $50 \%$ seeds germinated when treated with AsA in comparison with no germination in the absence of AsA, whereas 10 and $20 \mathrm{~mm}$ AsA had generally negative effects. At the higher temperature regime of $15 / 25^{\circ} \mathrm{C}$, both 5 and $10 \mathrm{~mm}$ AsA treatments alleviated the salinity effect, but no such effect was observed at $20 \mathrm{~mm}$ treatment. The salinity effect on germination of P. karka was alleviated in the presence of $5 \mathrm{~mm}$ AsA at $20 / 30^{\circ} \mathrm{C}$, at which $80 \%$ seeds germinated at $500 \mathrm{~mm}$ of $\mathrm{NaCl}$. At the warmer thermo-period of $25 / 35^{\circ} \mathrm{C}$, seed germination was significantly inhibited in both non-saline and saline conditions, and application of AsA further inhibited seed germination. The rate of germination was also significantly improved by the application of lower concentrations ( 5 and $10 \mathrm{~mm}$ ) of AsA at all thermoperiods except at $25 / 35^{\circ} \mathrm{C}$ (Figure 2).

Table 2 Two-way ANOVA for percentage germination and rate of germination in seeds of Dichanthium annulatum and Eragrostis ciliaris.

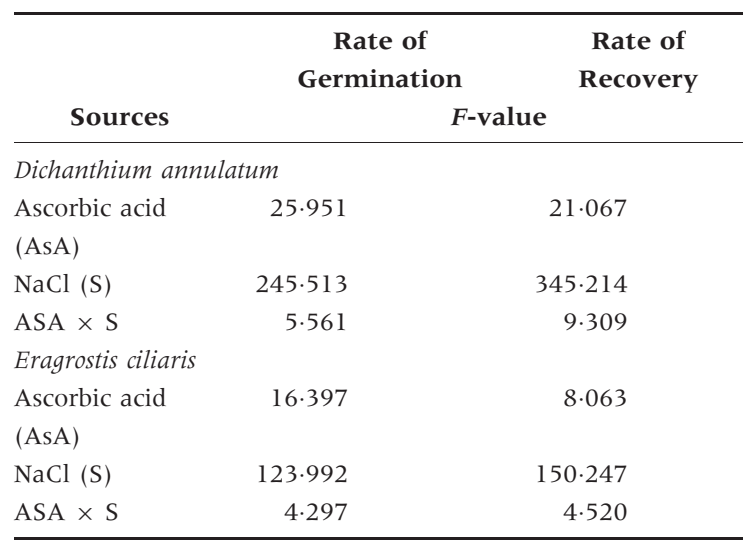

Numbers represent $F$-values significant at $P<0.001$. 


\section{Dichanthium annulatum and Eragrostis ciliaris}

A two-way ANova indicated significant $(P<0.001)$ effects for $\mathrm{NaCl}$ and AsA on seed germination for both $D$. annulatum and E. ciliaris (Table 2). Increase in $\mathrm{NaCl}$ concentration progressively decreased germination in both species, whereas the application of AsA stimulated germination of $E$. ciliaris but reduced it in $D$. annulatum (Table 3); this response was dependent on the concentration of AsA applied. Application of AsA alleviated the salinity effect in E. ciliaris; in its absence, none of the seeds germinated above $125 \mathrm{~mm}$. Only $4 \%$ of seeds germinated at $150 \mathrm{~mm} \mathrm{NaCl}$ in the presence of $20 \mathrm{~mm}$ AsA. At low AsA level ( $5 \mathrm{~mm}$ ), only a few seeds germinated above $125 \mathrm{~mm} \mathrm{NaCl}$ (Table 3). A low germination was observed in D. annulatum seeds treated with $400 \mathrm{~mm}$ $\mathrm{NaCl}$ and 25 mм AsA (Table 3).
The rate of germination progressively decreased with increasing $\mathrm{NaCl}$ concentration in both these species (Table 3). Increasing the AsA concentration increased the germination rate, but there was no significant difference between AsA concentrations in E. ciliaris seeds, although $D$. annulatum showed significant difference $(P<0.0001)$ between AsA and $\mathrm{NaCl}$ concentrations on the germination rate (Table 2 ).

\section{Discussion}

Seed germination is generally inhibited under saline conditions, and the effect is accentuated when temperature conditions deviate from optimum (Khan and Gul, 2006). Our results indicated that, in the case of P. karka, warmer temperature regimes prevented more seed from germinating. Osmotic and ionic stress

Table 3 Total (\%) germination and rate of germination (mean \pm standard error) at the end of the experiment for Dichanthium annulatum and Eragrostis ciliaris in different salinities with various concentrations of ascorbic acid (AsA).

\begin{tabular}{|c|c|c|c|c|c|c|}
\hline \multirow[b]{2}{*}{$\begin{array}{l}\text { ASA } \\
(\mathrm{m} м)\end{array}$} & \multirow[b]{2}{*}{$\begin{array}{l}\mathrm{NaCl} \\
(\mathrm{mM})\end{array}$} & \multicolumn{2}{|c|}{ Dichanthium annulatum } & \multirow[b]{2}{*}{$\begin{array}{l}\mathrm{NaCl} \\
(\mathrm{mM})\end{array}$} & \multicolumn{2}{|c|}{ Eragrostis ciliaris } \\
\hline & & $\begin{array}{c}\text { Germination } \\
(\%)\end{array}$ & $\begin{array}{c}\text { Rate of } \\
\text { germination }\end{array}$ & & $\begin{array}{c}\text { Germination } \\
(\%)\end{array}$ & $\begin{array}{c}\text { Rate of } \\
\text { germination }\end{array}$ \\
\hline \multirow[t]{6}{*}{0} & 0 & $100 \cdot 0 \pm 0 \cdot 0$ & $50 \cdot 0 \pm 0 \cdot 00$ & 0 & $63.0 \pm 1.9$ & $27 \cdot 2 \pm 1 \cdot 0$ \\
\hline & 100 & $85 \cdot 0 \pm 2 \cdot 5$ & $24 \cdot 2 \pm 1 \cdot 56$ & 25 & $54 \cdot 0 \pm 8 \cdot 8$ & $24 \cdot 0 \pm 3 \cdot 9$ \\
\hline & 200 & $31 \cdot 0 \pm 5 \cdot 7$ & $10 \cdot 9 \pm 2 \cdot 31$ & 75 & $18 \cdot 0 \pm 6 \cdot 6$ & $8 \cdot 4 \pm 3 \cdot 0$ \\
\hline & 300 & $41 \cdot 0 \pm 1 \cdot 0$ & $14.6 \pm 0.63$ & 100 & $17 \cdot 0 \pm 1 \cdot 9$ & $6 \cdot 2 \pm 0 \cdot 5$ \\
\hline & 400 & $24 \cdot 0 \pm 2 \cdot 8$ & $7 \cdot 1 \pm 1 \cdot 05$ & 125 & $6 \cdot 0 \pm 2 \cdot 0$ & $1.9 \pm 1.2$ \\
\hline & 500 & $0 \cdot 0 \pm 0 \cdot 0$ & $0 \cdot 0 \pm 0 \cdot 00$ & 150 & $0 \cdot 0 \pm 0 \cdot 0$ & $0 \cdot 0 \pm 0 \cdot 0$ \\
\hline \multirow[t]{6}{*}{5} & 0 & $58 \cdot 0 \pm 8 \cdot 0$ & $26 \cdot 1 \pm 3 \cdot 64$ & 0 & $76 \cdot 0 \pm 13 \cdot 9$ & $36 \cdot 0 \pm 6 \cdot 7$ \\
\hline & 100 & $20 \cdot 0 \pm 1 \cdot 4$ & $26 \cdot 0 \pm 4 \cdot 16$ & 25 & $46 \cdot 0 \pm 3 \cdot 5$ & $17 \cdot 3 \pm 0 \cdot 6$ \\
\hline & 200 & $20 \cdot 0 \pm 6 \cdot 9$ & $6 \cdot 9 \pm 2 \cdot 25$ & 75 & $50 \cdot 0 \pm 3.45$ & $14 \cdot 8 \pm 0 \cdot 8$ \\
\hline & 300 & $20 \cdot 0 \pm 0 \cdot 6$ & $6 \cdot 3 \pm 2 \cdot 19$ & 100 & $30 \cdot 0 \pm 1 \cdot 2$ & $7 \cdot 1 \pm 0$ \\
\hline & 400 & $0 \cdot 0 \pm 0 \cdot 0$ & $0 \cdot 0 \pm 0 \cdot 00$ & 125 & $10 \cdot 0 \pm 1 \cdot 2$ & $2 \cdot 2 \pm 0 \cdot 4$ \\
\hline & 500 & $0 \cdot 0 \pm 0 \cdot 0$ & $0 \cdot 0 \pm 0 \cdot 00$ & 150 & $2 \cdot 0 \pm 1 \cdot 2$ & $0 \cdot 1 \pm 0 \cdot 1$ \\
\hline \multirow[t]{6}{*}{10} & 0 & $78 \cdot 0 \pm 3 \cdot 5$ & $36 \cdot 3 \pm 2 \cdot 25$ & 0 & $100 \cdot 0 \pm 0 \cdot 0$ & $46 \cdot 4 \pm 0 \cdot 3$ \\
\hline & 100 & $54 \cdot 0 \pm 5 \cdot 8$ & $21 \cdot 3 \pm 1 \cdot 67$ & 25 & $64 \cdot 0 \pm 2 \cdot 3$ & $23 \cdot 4 \pm 1 \cdot 0$ \\
\hline & 200 & $24 \cdot 0 \pm 4 \cdot 6$ & $9 \cdot 7 \pm 1.33$ & 75 & $48 \cdot 0 \pm 2 \cdot 3$ & $17 \cdot 1 \pm 1 \cdot 0$ \\
\hline & 300 & $16 \cdot 0 \pm 2 \cdot 3$ & $5 \cdot 2 \pm 0 \cdot 46$ & 100 & $56 \cdot 0 \pm 2 \cdot 3$ & $15 \cdot 6 \pm 0 \cdot 0$ \\
\hline & 400 & $0 \cdot 0 \pm 0 \cdot 0$ & $0 \cdot 0 \pm 0 \cdot 00$ & 125 & $16 \cdot 0 \pm 4 \cdot 6$ & $4 \cdot 5 \pm 1 \cdot 2$ \\
\hline & 500 & $0 \cdot 0 \pm 0 \cdot 0$ & $0 \cdot 000 \cdot 00$ & 150 & $10 \cdot 0 \pm 3 \cdot 5$ & $1 \cdot 0 \pm 0 \cdot 2$ \\
\hline \multirow[t]{6}{*}{20} & 0 & $88 \cdot 0 \pm 6 \cdot 9$ & $37 \cdot 5 \pm 1 \cdot 44$ & 0 & $70 \cdot 7 \pm 13 \cdot 3$ & $30 \cdot 0 \pm 5 \cdot 8$ \\
\hline & 100 & $46 \cdot 0 \pm 8 \cdot 1$ & $18.9 \pm 2.94$ & 25 & $76 \cdot 0 \pm 6 \cdot 9$ & $29 \cdot 2 \pm 3 \cdot 2$ \\
\hline & 200 & $44 \cdot 0 \pm 2 \cdot 3$ & $19 \cdot 6 \pm 0.92$ & 75 & $50 \cdot 0 \pm 3 \cdot 5$ & $15 \cdot 6 \pm 0 \cdot 6$ \\
\hline & 300 & $04 \cdot 0 \pm 2 \cdot 3$ & $1.6 \pm 0.92$ & 100 & $40 \cdot 0 \pm 4 \cdot 6$ & $11 \cdot 6 \pm 1 \cdot 0$ \\
\hline & 400 & $0 \cdot 0 \pm 0 \cdot 0$ & $0 \cdot 0 \pm 0.00$ & 125 & $28 \cdot 0 \pm 2 \cdot 3$ & $5 \cdot 8 \pm 1 \cdot 4$ \\
\hline & 500 & $0 \cdot 0 \pm 0 \cdot 0$ & $0 \cdot 0 \pm 0.00$ & 150 & $4 \cdot 0 \pm 0 \cdot 0$ & $1 \cdot 3 \pm 0 \cdot 2$ \\
\hline \multirow[t]{6}{*}{25} & 0 & $54 \cdot 0 \pm 3 \cdot 5$ & $23 \cdot 3 \pm 1 \cdot 21$ & 0 & $52 \cdot 0 \pm 0 \cdot 7$ & $22 \cdot 6 \pm 2 \cdot 1$ \\
\hline & 100 & $52 \cdot 0 \pm 1 \cdot 3$ & $22 \cdot 4 \pm 0 \cdot 46$ & 25 & $60 \cdot 0 \pm 0 \cdot 4$ & $25 \cdot 4 \pm 3 \cdot 4$ \\
\hline & 200 & $22 \cdot 0 \pm 0 \cdot 4$ & $8 \cdot 2 \pm 0 \cdot 12$ & 75 & $44 \cdot 0 \pm 0 \cdot 8$ & $15 \cdot 6 \pm 2 \cdot 3$ \\
\hline & 300 & $14 \cdot 0 \pm 0 \cdot 5$ & $5 \cdot 4 \pm 2 \cdot 19$ & 100 & $56 \cdot 0 \pm 1 \cdot 0$ & $16 \cdot 6 \pm 2 \cdot 0$ \\
\hline & 400 & $2 \cdot 0 \pm 0 \cdot 6$ & $0.5 \pm 0.29$ & 125 & $12 \cdot 0 \pm 1 \cdot 0$ & $2 \cdot 9 \pm 0 \cdot 8$ \\
\hline & 500 & $0 \cdot 0 \pm 0 \cdot 0$ & $0 \cdot 0 \pm 0 \cdot 00$ & 150 & $2 \cdot 0 \pm 1 \cdot 2$ & $0.6 \pm 0.4$ \\
\hline
\end{tabular}


increased under suboptimal temperature conditions and inhibited seed germination. These stresses may cause imbalance in growth regulators and possible increase in ROS production (Sairam and Tyagi, 2004; Wang et al., 2004; Neto et al., 2006). Accumulation of $\mathrm{Na}^{+}$may enhance electrolyte leakage, decrease hydrolytic enzyme activity and increase peroxidase activity (Dionisio-Sese and Tobita, 1998; Imlay, 2003; Demiral and Türkan, 2004; Neto et al., 2006).

In our study, inclusion of AsA (at 5 and $10 \mathrm{~mm}$ ) in the growth medium alleviated the salinity effects on the germination of P. karka at lower temperature regimes. In the case of $D$. annulatum and E. ciliaris, the effect of AsA was found to be species specific (i.e. pretreatment with AsA alleviated the salinity effect of $\mathrm{NaCl}$ on seed germination of E. ciliaris, whereas it suppressed the effect in $D$. annulatum at all salinity levels). Khan and Gul (2006) indicated that the effect of AsA on salinity tolerance varied depending on plant species (i.e. its application alleviated salinity effects on Atriplex stocksii and Suaeda fruticosa, whereas no effect was found on Aeluropus lagopoides, Arthrocnemum macrostachyum, Desmostachya bipinnata and Haloxylon stocksii).

In this study, the application of AsA significantly alleviated salinity stress on the germination of P. karka seeds, but it failed to compensate for warmer temperature stress. It can be argued that the response of a system to a particular stress may be different from a combination of stresses as observed here in the presence of both salinity and high temperature.

Seeds pre-treated with $20 \mathrm{~mm}$ AsA showed high germination in E. ciliaris at each salinity level compared to the nil-AsA control. However, seed germination of $D$. annulatum was inhibited by AsA application, thereby suggesting that a single antioxidant is not responsible for successful protection against ROS in a stressed plant (Foyer et al., 1994) and a complete set of antioxidant defence systems is required to increase stress tolerance. From the present research, it is concluded that the effect of AsA on seed germination is species specific and it may suppress or alleviate the salinity stress. There is no universality in response; therefore, this warrants cautious and careful consideration not only of the nature of a particular antioxidant but also of its concentration for the species under test. Furthermore, environmental factors such as salinity and temperature may become significant determinants of the response in individual cases.

\section{References}

Abidin Z., Ansari R. and Khan M.A. (2011)

Halophytes: potential source of lignocellulosic biomass for ethanol production. Biomass and Bioenergy, 35, 18181822.
Agarwal P.K., Shukla P.S., Gupta K. and Jha B. (2012) Bioengineering for salinity tolerance in plants: state of the art. Molecular Biotechnology, DOI 10.1007/ s12033-012-9538-3.

Arrigoni O. and De Tullio M.C. (2000) The role of ascorbic acid in cell metabolism: between gene-directed functions and unpredictable chemical reactions. Journal of Plant Physiology, 157, 481-488.

Cope T.A. (1982) Poaceae. In: Nasiir E. and Ali S.I. (eds) Flora of Pakistan. Karachi, Pakistan: University of Karachi.

De Tullio M.C. and Arrigoni O. (2003) The ascorbic acid system in seeds: to protect and to serve. Seed Science Research, 13, 249-260.

Demiral J.T. and Türkan İ. (2004) Comparative lipid peroxidation, antioxidant defense systems and proline content in roots of two rice cultivars differing in salt tolerance. Environmental and Experimental Botany, 53, 247-257.

Dionisio-Sese M.L. and Toвita S. (1998) Antioxidant responses of rice seedlings to salinity stress. Plant Science, $135,1-9$.

Foyer C.H. and Noctor G. (2011) Ascorbate and glutathione: the heart of the redox hub. Plant Physiology, 155, 2-18.

Foyer C.H., Lelandais M. and Kunert K.J. (1994) Photo-oxidative stress in plants. Physiologia Plantarum, 92, 696-717.

Garnczarska M. and Wojtyla E. (2008) Differential response of antioxidative enzymes in embryonic axes and cotyledons of germinating lupine seeds. Acta Physiologia Plantarum, 30, 427-432.

Hernández J.A. and Almansam S. (2002) Short-term effects of salt stress on antioxidant systems and leaf water relations of pea leaves. Physiologia Plantarum, 115, 25l-257.

Horemans N., Foyer C.H. and Asard H. (2000) Transport and action of ascorbate at the plasma membrane. Trends in Plant Science, 5, 263-266.

Imlay J.A. (2003) Pathways of oxidative damage. Annual Review of Microbiology, 57, 395-418.

Khan M.A. and Gul B. (2006) Halophyte seed germination. In: Khan, M.A., Weber and D.J. (eds) Eco-physiology of high salinity tolerant plants, pp. 11-30. The Netherlands: Springer.

KHAN M.A. and UNGAR I.A. (1999) Effect of salinity on the seed germination of Triglochin maritima under various temperature regimes. Great Basin Naturalist, 59, $144-150$.

Khan M.A., Ahmed M.Z. and Hameed A. (2006a) Effect of sea salt and L-ascorbic acid on the seed germination of halophytes. Journal of Arid Environments, 67, 535540.

Khan M.A., Ansari R., Gul B. and Qadir M. (2006b) Crop diversification through halophyte production on salt prone land resources. CAB Reviews: Perspectives in Agriculture, Veterinary Science, Nutrition and Natural Resources, 1, No. 48, 8pp. CABI Publishing.

Kocsy G., Galiba G. and Brunold C. (2001) Role of glutathione in adaptation and signaling during chilling 
and cold acclimation in plants. Physiologia Plantarum,

113, 165-167.

Koyro H.-W., Kh an M.A. and Lieth H. (2011) Halophytic crops: a resource for the future to reduce the water crisis? Emirates Journal of Food and Agriculture, 23, 1-16.

Kranner I., Roach T., Beckett R.P., Whitaker C. and FARIDA V.M. (2010) Extra cellular production of reactive oxygen species during seed germination and early seedling growth in Pisum sativum. Journal of Plant Physiology, 167, 805-811.

Müller K., Linkies A., Vreeburg R.A.M., Fry S.C., Krieger-Liszkay A. and Leubner-Metzger G. (2009) In Vivo cell wall loosening by hydroxyl radicals during Cress seed germination and elongation growth. Plant Physiology, 150, 1855-1865.

Neto A., Prisco J.T., Eneas-Filho J., Braga De Abreu C.E. and Gomes- Filho E. (2006) Effect of salt stress on antioxidative enzymes and lipid peroxidation in leaves and roots of salt tolerant and salt sensitive maize genotypes. Environmental and Experimental Botany, 52, 87-94.

Noctor G. and Foyer C.H. (1998) Ascorbate and glutathione: keeping active oxygen under control. Annual Review of Plant Physiology and Plant Molecular Biology, 49, 249-279.

Ogawa K. and Iwabuchi M. (2001) A mechanism for promoting the germination of Zinnia elegans seeds by hydrogen peroxide. Plant and Cell Physiology, 42, 286-291.
Rosa - Innes R. (1977) A manual of Ghana grasses. London, UK: Ministry of Overseas Development.

S Airam R.K. and Tyagi A. (2004) Physiology and molecular biology of salinity stress tolerance in plants. Current Science, 86, 407-421.

Schopfer P., Plachy C. and Frahry G. (2001) Release of reactive oxygen intermediates (superoxide radicals, hydrogen peroxide, and hydroxyl radicals) and peroxidase in germinating radish seeds controlled by light, gibberellins, and abscisic acid. Plant Physiology, 125, 1591-1602.

Shaо H.B., Chu L.Y., Zhaо C.-X., Guo Q.J. and LiU X.A. (2006) Plant gene regulatory network system under abiotic stress. Acta Biologica Szegediansis, 50, 1-9.

Shaо H.B., Chu L.Y., Lu Z.H. and Kang C.M. (2008) Primary antioxidant free radical scavenging and redox signaling pathways in higher plant cells. International Journal of Biological Sciences, 4, 8-14.

S Mirnoff N. (2000) Ascorbate biosynthesis and function in photo-protection. Philosophical Transactions of the Royal Society, 355, 1455-1464.

SPS S (1999) SPSS 7.0 for windows update. Chicago, IL, USA: SPSS.

Wang B., Luttge U. and Ratajezak R. (2004) Specific regulation of SOD isoforms by $\mathrm{NaCl}$ and osmotic stress in leaves of the $\mathrm{C}_{3}$ halophyte Suaeda salsa L. Journal of Plant Physiology, 161, 285-289. 